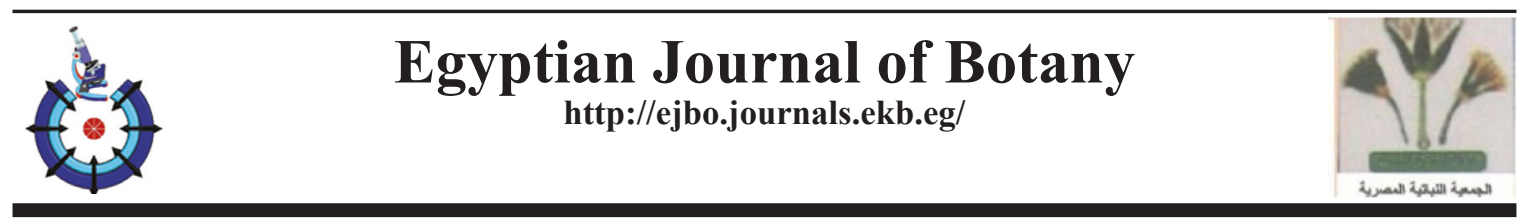

\title{
Assessment of Fuel Properties Produced from Tamarix nilotica and Pluchea dioscoridis Plants
}

\author{
Abeer Abdelrazk Ahmed Farag Younis \\ Botany Department, Faculty of Science, Ain Shams University,11566, Cairo, Eygpt.
}

\begin{abstract}
$\mathbf{N}$ OWADAYS, there is a great demand concerning searching about renewable energy sources. Therefore, wild plants such as Tamarix nilotica and Pluchea dioscoridis could be used as fossil fuel-alternative to meet the huge increments in the energy demand. The aerial parts of T. nilotica were collected from the Cairo-Suez road, while those of $P$. dioscoridis were collected from Wadi Hagul, Egypt. The biofuel generating compounds including lipids, carbohydrates, cellulose, pectin and lignin were assayed. The physico-chemical properties of the produced biodiesel were calculated. The obtained results indicated that, the high cellulose content $(25.02 \%)$ of $T$. nilotica increases its potentiality for bioethanol production. The GCMS analysis showed that $P$. dioscoridis displayed the highest levels of saturated fatty acid (SFAs) and a desirable degree of unsaturation (DU). The biodiesel properties in terms of iodine value (IV), saponification number (SN), cetane number (CN), oxidative stability (OS), high heating value (HHV), kinematic viscosity $(\eta)$ and density $(\rho)$ for both species were within the recommended standards and mostly met the criteria required to be a diesel substitute compared with the international biodiesel standards. Particularly biodiesel produced from $P$. dioscoridis has good and suitable engine parameters (SN 196.3, IV 76.81 and CN 114.18).
\end{abstract}

Keywords: Biodiesel properties, Bioethanol, Pluchea dioscoridis, Tamarix nilotica.

\begin{abstract}
Abbreviations: ASTM, American Society of the International Association for Testing and Materials; CFPP, cold filter-plugging point; $\mathrm{CN}$, cetane number; DU, degree of unsaturation; EN, European Nations; FAMEs, fatty acid methyl esters; GC-MS, gas chromatography- mass spectrometry; HHV, high heating value; HPLC, high performance liquid chromatography; IV, iodine value; LCSF, long chain saturated factor; MUFAs, mono-unsaturated fatty acids; OS, oxidative stability; PUFAs, poly-unsaturated fatty acids; SFAs, saturated fatty acids; SN, saponification number; UI, unsaturation index; $\eta$, kinematic viscosity; $\rho$, density.
\end{abstract}

\section{Introduction}

The world reserves of fossil fuel as raw materials for primary energy are, clearly, restricted which requires developing and searching for renewable energy resources. Researchers worldwide have revealed many alternative resources for energy, which have the potential to reduce the demand of petroleum-based energy, particularly, biofuel production from different bio-resources. Recently, insights have been directed towards biomassbased biofuels (Yadav et al., 2018), due to its low cost, largely environment-friendly, produces less toxic pollutants (Alptekin, 2017; Mohamed Shameer et al., 2017), as well as have complete combustion similar to diesel obtained from fossil ones (Singh \& Singh, 2010). In this regard, usage of lignocellulosic biomass and edible vegetable oils as feedstocks were better alternative choices for biofuel production (Hadar, 2013). Generally, oils from edible vegetables such as those from rapeseed, soybean, sunflower and palm have been used for fuel production (Leung et al., 2010;

\footnotetext{
${ }^{\#}$ Corresponding author email: abeeryounis@sci.asu.edu.eg $\quad$ Tel: 01128459929

Received 26/7/2019; Accepted 6/10/2019

DOI: 10.21608/ejbo.2019.15138.1340

Edited by: Prof. Dr. Wedad Kasim, Faculty of Science, Tanta University, Tanta, Egypt.

C2020 National Information and Documentation Center (NIDOC)
} 
Balat, 2011). However, the use of edible crops as feedstock for this purpose may result in a food crisis and high prices. For keep pace with the global challenge posed by the energy crisis countries around the world and to avoid starvation in low-income countries, using non-edible plants are paying a very crucial attention to renewable energy resource and should be encouraged (Atabani et al., 2012, 2013). Previous reports indicated that sugarcane, wheat straw, rice straw and corn stover could be used as promising nonedible lignocellulose-based bioethanol producers (Kadam \& McMillan, 2003; Kim \& Dale, 2004; Yousuf, 2012). Moreover, others indicated alternate vegetable oil production includes some species such are Aleurites moluccana, Croton megalocarpus, Moringa oleifera and Pachira glabra suitable for biodiesel production (Kibazohi \& Sangwan, 2011). Until now, using non-edible plants for biofuel production have received little attention in Africa and Asia. For instance, few reports in India for Azam et al. (2005) on weed seeds, Verma \& Verma (2015) on Jatropha curcas, Abideen et al. (2015) and Patel et al. (2019) on some halophytes as well as for Ahmad et al. (2014) on Silybum marianum, Guil-Guerrero et al. (2017) on Mediterranean basin wild species and Guil-Layneza et al. (2019) on some tropical plants. Such regions having plant communities with highly diverse, stability, and productivity over the long-term, which make it more relevant to use as suitable alternative source of energy. Therefore, using resources in these regions which have been unutilized is considered the corner stones when displaying usage of bioenergy in the future.

Several biofuel resources have been explored include biomass, biogas (Murphy \& McCarthy, 2005), alcohols (Kumar et al., 2009) and biodiesel (Knothe, 2010). Some of them can be used directly while others need to be synthesized to convey the related properties closer to conventional fuels. Among biomass-based biofuels, biodiesel is the most sustainable alternative to the fossil diesel fuel (Sitepu et al., 2014; Sajid et al., 2016; Knothe \& Razon, 2017). The most important parameters for potential biodiesel are iodine value (IV), saponification number (SN), cetane number (CN), cold filter plugging point (CFPP), oxidative stability (OS), high heating value (HHV), kinematic viscosity $(\eta)$ and density $(\rho)$ (RamirezVerduzco et al., 2012). Biodiesel chemically produced by transesterification of fatty acids forming fatty acid methyl esters (FAMEs) (Leung et al., 2010; Patel et al., 2016 b).The length of carbon chain and the degree of unsaturation of FAME are important factors in determining the physiochemical characteristics of biodiesel(Verma et al., 2016; Wakil et al., 2015). High saturation in fatty acid profile enhances the $\mathrm{CN}$, viscosity, and cold flow performance while unsaturation in fatty acid profile enhances the density and high heating value of biodiesel (Jakeria et al., 2014). Therefore, potential biodiesel must meet the criteria set up by international standards such as ASTM D6751, EN 14214 and EN 14213 (biodiesel for heating purpose) for biodiesel (Atadashi et al., 2010). Hence, selection of the most appropriate species based on their fatty acids composition with full agreement with the biodiesel standards is a very challenging task. Nevertheless, constitutes a suitable option to replace or complement conventional fuels (Aransiola et al., 2014; GuilGuerrero et al., 2014).

In Egypt, petroleum energy resources are rare, so bioresources as wild plants could be used for biodiesel production to meet the energy demand. Tamarix nilotica (Ehrenb.) Bunge is a member of Tamaricaceae. The genus Tamarix is native to Africa, includes about 50 species, T. nilotica is an evergreen tree or shrub that can grow up to $5 \mathrm{~m}$ tall and well-known as a medicinal plant (Migahid, 1978). Tamarix spp. trees occupy saline habitats and are well known for their fast growth rates which increase their opportunity for biofuel production due to their biomass. Another wild plant, Pluchea dioscoridis (L.) DC. (syn. Conyzadioscoridis. Desf.) (Asteraceae) is a common perennial weed in Egypt (Takholm, 1974). It was used in the traditional medicine in Egypt and was chosen for this study because it is a rich source of bioactive compounds (Boulos $\&$ El-Hadidi, 1984). The purpose of our research is focused on assessment the potentiality of both T. nilotica and $P$. dioscoridis as non-edible wild plants for biofuel production.

\section{Materials and Methods}

\section{Plant material}

Tamarix nelotica and Pluchea dioscoridis plants were selected for assessment of biofuel production. The aerial portions of $T$. nelotica were collected from the Cairo-Suez road, Egypt, delimited by latitudes $29^{\circ} 58^{\prime} 04.9 \mathrm{~N}$. and longitudes $32^{\circ} 08^{\prime} 25.4 \mathrm{E}$. While those of $P$. 
dioscoridis were collected from Wadi Hagul, located in the northern portion of the Eastern Desert of Egypt within Cairo-Suez district, delimited by latitudes ' $29^{\circ} 48^{\prime} 28-29^{\circ} 57^{\prime} 43^{\prime}$ " N. and longitudes " $32^{\circ} 09^{\prime} 32-32^{\circ} 17 ’ 27^{\prime}$ " E. The airdried and fresh aerial parts were subjected to oil extraction and other biochemical analysis.

\section{Carbohydrates content}

Total soluble and insoluble carbohydrates were extracted following the method of Homme et al. (1992) and determined using anthrone reagent (Fairbairn, 1953). The major structural carbohydrates (cellulose, pectin and lignin) were determined by chemical analysis. It was carried out in an Ankom 200 Fiber AnalyzerTM (ANKOM Technology, USA) in accordance with the fiber analysis method (Soleimani et al., 2008; Jin et al., 2013). The percentage contents of cellulose, pectin and lignin were determined and the average values of the three samples were reported.

\section{Ash content}

Total ash content was determined by the furnaces incineration gravimetric method described by James (1995) and AOAC (1984).

\section{Phenolic compounds}

Phenolic compounds were extracted according to method of Haminiuk et al. (2011). The extract was used to quantify the phenolic acids by high performance liquid chromatography (HPLC):(HPLC instrument E-Chrom Tech, LC 1620), Ultraviolet (UV) detector set at $254 \mathrm{~nm}$, gradient separation flow rate of $1.0 \mathrm{ml} / \mathrm{min}$ and $20 \mu \mathrm{l}$ injection volume. The chromatographic separation column was C18 (Shodex C18-1205 4E: $4.6 \times 250 \mathrm{~mm}$ ), eluent (mobile phase): acetonitrile: ultrapure deionized water (75: 25 $\mathrm{v} / \mathrm{v}$ ) and the elution program: $0 \mathrm{~min} 5 / 95 ; 10 \mathrm{~min}$ 25/75; 20min 50/50; 30min 100/0; 40min 5/95.

\section{Oil extraction}

The total oil was extracted from $10 \mathrm{~g}$ of aerial portions of the investigated species by a solvent extraction method using chloroform-methanol (2:1 v/v) (Mishra et al., 2015). The extracted oil samples were converted to corresponding fatty acid methyl esters (FAMEs) by transmethylation (Pandey et al., 2015). The FAMEs were extracted by deionized water-hexane mixture $(1: 2 \mathrm{v} / \mathrm{v})$, then recovered in $2 \mathrm{ml}$ of hexane, dried under $\mathrm{N}_{2}$ and finally dissolved in $200 \mu 1$ hexane.

\section{Gas chromatography analysis}

The extracted FAMEs sample of each plant were analyzed by gas chromatography- mass spectrometry (GC-MS) (Thermo Scientific TRACE 1310, Italy) attached with ISQLT single quadrupole mass spectrometer using a silica capillary column $(30 \mathrm{~m} \times 0.25 \mathrm{~mm} \times 0.25 \mathrm{~mm})$. Pure helium was usedas a carrier gas. The column temperature programranged from $40^{\circ} \mathrm{C}$ to $240^{\circ} \mathrm{C}$ at a fixed rate of $5^{\circ} \mathrm{C} / \mathrm{min}$. The injection volume was $1 \mu \mathrm{l}$ for $67 \mathrm{~min}$ and temperature was $240^{\circ} \mathrm{C}$. The mass spectrometer operated in electron compact mode with the electron energy of $70 \mathrm{eV}$ and the temperature of the ion sources and quadrupole was $200^{\circ} \mathrm{C}$.

The FAME swere identified by comparing their retention time with the database of Wiley Registry 8e library, then subjected to characterization for estimating their fuel properties. Total saturated fatty acids (SFAs) and unsaturated fatty acids (UFAs) were determined by summation of the percent quantity of corresponding fatty acids (Patel et al., 2016 a). The unsaturation index (Poerschmann et al., 2004), degree of unsaturation (Yu et al., 2012) were calculated using the following formula:

Degree of unsaturation $(D U)=($ MUFAs $w \%)+2$ $\times($ PUFAs $\mathrm{w} \%)$

Unsaturation index $(\mathrm{UI})=\Sigma(\mathrm{UFAs} \mathrm{w} \% \times$ number of double bonds)

where, MUFAs, mono-unsaturated fatty acids and PUFAs, poly-unsaturated fatty acids.

$\mathrm{SN}=\Sigma(560 \times \mathrm{FA} \%) / \mathrm{MWi}$

$\mathrm{IV}=\Sigma(254 \times \mathrm{D} \times \mathrm{FA} \%) / \mathrm{MWi}$

where, D is the number of double bonds, and MWi is the molecular mass of each fatty acid (Kalayasiri et al., 1996).

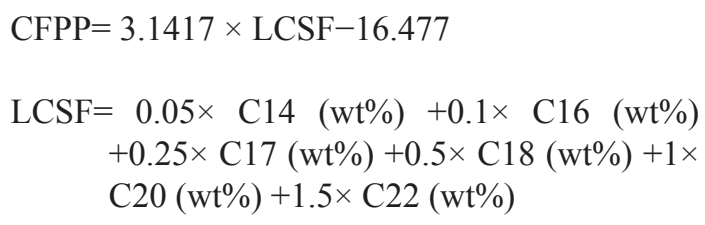

where LCSF is the long-chain saturated factor, and $\mathrm{C} 14, \mathrm{C} 16, \mathrm{C} 17, \mathrm{C} 18, \mathrm{C} 20$, and $\mathrm{C} 22$ are the $\mathrm{wt} \%$ of LCSFAs present in each oil (Ramos et al., 
2009; Gornaś \& Rudzińska, 2016).

OS $(h)=(117.9295 / X)+2.5905$

where $\mathrm{X}$ is the content of poly unsaturated fatty acids (PUFAs) (Park et al., 2008).

$\mathrm{CN}=46.3+5458 / \mathrm{SN}-0.225 \times \mathrm{IV}$

While HHV was calculated also as indicated by Demirbas (2008).

$\operatorname{HHV}(\mathrm{MJ} / \mathrm{kg})=49.43-0.041 \times \mathrm{SN}-0.015 \times \mathrm{IV}$

Kinematic viscosity $(\eta)$ and density $(\rho)$ were computed from the individual physical properties of their respective FAMEs compositions. Data of the physical properties for FAMEs were taken from Ramirez-Verduzco et al. (2012).

\section{Statistical analysis}

Statistical analysis was carried out using the software package SPSS v20.0 (SPSS Inc., Chicago, USA), and the comparison of the averages of each treatment was based on a oneway analysis of variance (ANOVA) test at a significance level of $5 \%(\mathrm{P} \leq 0.05)$.

\section{Results and Discussion}

The cellulosic biomass properties of $T$. nilotica and $P$. dioscoridis for biofuel production are given in Fig. 1. Cellulosic biomass is currently the main interest of scientists for bioethanol production, in addition to fermentation of sugars directly derived from it. Results of this study indicated greater soluble sugar level $(6.2 \%)$ in $T$. nilotica compared with that of $P$. dioscoridis $(3.73 \%)$ (Fig. 1). Several investigators reported that, crops contain free sugars make them more cost-effective feedstocks in bioethanol industry (Ensinas et al., 2009; Dhaliwal et al., 2011; Rasmey et al., 2018). Furthermore, the cellulose content recorded in T. nilotica $(25.02 \%)$ was greater twofold than that of $P$. dioscoridis (10.04\%) (Fig. 1), which consequently, increasing the potentiality of $T$. nilotica for bioethanol production. Such results were concomitant with previous studies of Eshel et al. (2011) and Santi et al. (2014) who suggested that $T$. jordanis as promising biofuel candidate due to their high cellulose content. On the other hand, the lignin content represents about $22.63 \%$ in $T$. nilotica, while that of $P$. dioscoridis represents about $8.15 \%$ (Fig. 1). The lower content of lignin in $P$. dioscoridis is desirable and reduces the cost involved in biofuel production (Chen \& Dixon, 2007; Ding et al., 2012). However, removal of lignin from T. nilotica using diluted acid chloride at room temperature allows complete hydrolysis within several hours (Ding et al., 2012) in order to benefit of producing bioethanol from T. nilotica. In this respect, Schubert (2006) reported that lignocellulosic-derived biofuel has the potential to meet most of global conveyance fuel requirements with muchless impact on food supply, with lower agricultural inputs and less net carbon dioxide emissions than fossil fuels.

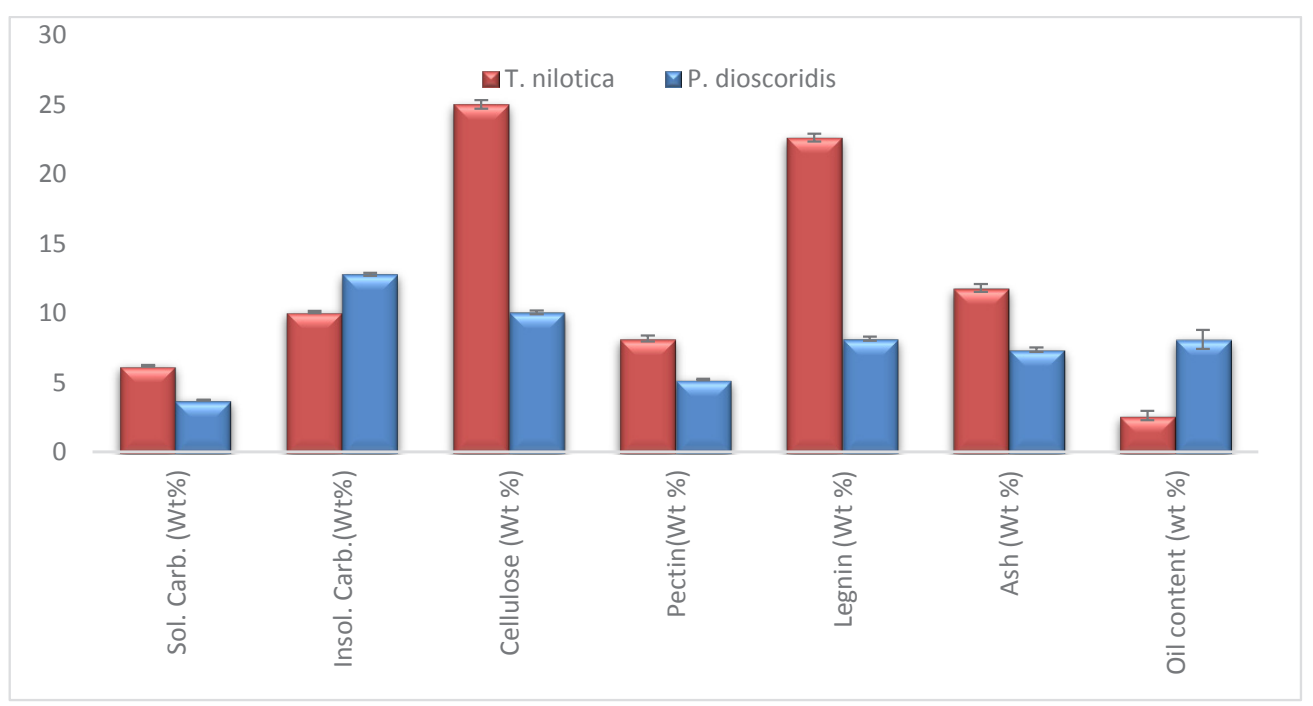

Fig. 1.The biomass characterization of $T$. nilotica and $\boldsymbol{P}$. dioscoridis [Values have been adjusted to a percentage basis (dry weight). Each value is the mean of three replicates $\pm \mathrm{SE}]$. 
Phenolic compounds compose a large class of phytochemicals that considered as natural antioxidants protect oil against oxidation. In this respect, Silva de Sousa et al. (2014) reported that the antioxidant activity of phenolic compounds controls the oxidative process of biodiesel during storage period and increasing its oxidative stability (OS). The HPLC analysis indicated that the common phenolic compounds such as ellagic acid, catechol and gallic acid were identified in both investigated species with remarkable contents in P. dioscoridis (Table 1). Meanwhile, coumaric acid $(13.01 \mu \mathrm{g} / \mathrm{ml})$ and protocatechuic $(15.21 \mu \mathrm{g} / \mathrm{ml})$ were detected in P. dioscoridis, however, resorcinol $(10.2 \mu \mathrm{g} /$ $\mathrm{ml}$ ) was distinguished in T. nilotica (Table 1). On the other hand, ash content is an important prerequisite for biofuels production (Abideen et al., 2014). Results indicated that the ash content of T. nilotica $(11.8 \%)$ was higher than that of $P$. dioscoridis $(7.36 \%)$ (Fig. 1) which attributed to saline habitats of T. nilotica (Abideen et al., 2012). In this respect, Cassida et al. (2005)reported that biodiesel properties like high heating value (HHV) is negatively associated with ash content; every $1 \%$ increase in ash concentration decreases HHV by $0.2 \mathrm{MJ} \mathrm{kg}^{-1}$ which in agreement with our (HHV) results will be mentioned later. Regarding the oil extraction for biodiesel production which adds economic value to the biomass for the investigated species, results indicate that the oil content percentage of $P$. dioscoridis was about (8.1\%) while that of T. nilotica was (2.62\%) (Fig. 1). Such results were comparable with some of others suggested biodiesel feedstock crops (Patel et al., 2019).

TABLE 1. HPLC analysis of phenolic acids ofT. niloticaand P.dioscoridis.

\begin{tabular}{lcc}
\hline $\begin{array}{l}\text { Phenolic acids } \\
(\mathbf{M g} / \mathbf{m l})\end{array}$ & T. nilotica & P. dioscoridis \\
\hline Ellagic acid & 12.54 & 27.66 \\
Catechol & 3.96 & 25.0 \\
Resorcinol & 10.2 & - \\
Gallic acid & 40.2 & 10.2 \\
Coumaric acid & - & 13.01 \\
Protocatechuic & - & 15.21 \\
acid & & \\
\hline
\end{tabular}

The fatty acid methyl esters (FAMEs) profile significantly influences the physicochemical properties of the resulting biodiesel (Hoekman et al., 2012; Gornaś \& Rudzińska, 2016). Chromatographic FAME sprofile of T. nilotica
(Fig. 2) showed that intense peaks for palmitic (C16:0), stearic (C18:0) and linoleic (C18:1) acids, which represent about $20.28,11.68$ and $6.27 \%$, respectively (Table 2). While, that of P. dioscoridis (Fig. 3) showed the most intense peak for palmitic acid (C16:0) represents about $38.26 \%$ (Table 2). Signals indicative for presence of linoleic (C18:1), linolenic (C18:3) and stearic (C18:0) acids were also detected with percentages of $16.72,16.07$ and $10.83 \%$, respectively (Table 2). Such results attributed to that these acids are the four major constituents of membrane fatty acids composition (Patel et al., 2019). Other fatty acids were also detected differentially in both investigated species (Table 2). However, the variability of FAMEs composition presented in Table 3 mainly assessed their suitability for diesel engines. The highest SFAs percentage $(58.82 \%)$ was detected in $P$. dioscoridis compared with that of T. nilotica (37.67\%) (Table 3). Moreover, the maximum MUFAs and PUFAs percentage were attained in $P$. dioscoridis concomitant with UI $(84.28 \%)$ and DU (68.21\%) values (Table 3 ). In this respect, Patel et al. (2017) reported that the presence of high SFAs in FAMEs alleviates the biodiesel to undergo auto-oxidation and thus increasing its self-life, while UFAs quantities determine its cold flow plugging properties. Therefore, it is important to control the fuel properties by optimizing the ratio of SFAs to UFAs. Such parameters of FAMEs have been used for evaluating engine performance criteria like iodine value (IV), saponification number $(\mathrm{SN})$ and cetane number $(\mathrm{CN})$ of biodiesel and assessed according to the specifications of the international biodiesel standards to explore the suitability of studied species for this purpose.

The quality of the T. nilotica and P. dioscoridis biodiesel was evaluated by the characterization parameters represented in Table 4 following the guidelines established by the biodiesel standards; ASTM D6751, EN 14214 and EN 14213 (biodiesel for heating purpose). Iodine value (IV) measures the addition of double bonds in fatty acids which are mainly related to its unsaturation (Toscano et al., 2012). High-quality biodiesel requires low IV, although the occurrence of unsaturated fatty acids in FAMEs is needed because it prevents FAMEs from solidifying. Oils having high IV are undesirable for biodiesel production, because unsaturated fatty acids react with oxygen-yielding peroxides. In this way, crosslinking can occur, and the material may become transformed into plastic- 
like polymers (Azam et al., 2005 ; Kalayasiri et al., 1996). Biodiesel standards by EN14214 indicates an iodine value ( $\mathrm{g} \mathrm{I}_{2} / 100 \mathrm{~g}$ oil) of $<115$ (Azam et al., 2005), while European biodiesel standards indicate an iodine value of $<120$. In the present study, the lower IV was recorded for $T$. nilotica $\left(17.25 \mathrm{~g} \mathrm{I}_{2} / 100 \mathrm{~g}\right)$ compared with that of $P$. dioscoridis (76.8g I $/ 100 \mathrm{~g}$ ) (Table 4). However, IV for $P$. dioscoridis is more desirable according to previous results of Guil-Laynez et al. (2019) who reported that IV higher than 38.5 has been indicated as required. Another critical measure for selection of the suitable biodiesel is the $\mathrm{SN}$, it is depending upon the chain length or the molecular weight of fatty acids forming the biodiesel (Gopinath et al., 2009). Results indicated that the higher $\mathrm{SN}$ was determined in $P$. dioscoridis $(196.3 \mathrm{mg} / \mathrm{g})$ (Table 4), which attributed to its higher percentage of SFAs (Table 3) mainly palmitic (C16:0) and myristic (C14:0) (Table 2) and thus improving the stability of the produced biodiesel (Akbar et al., 2009).

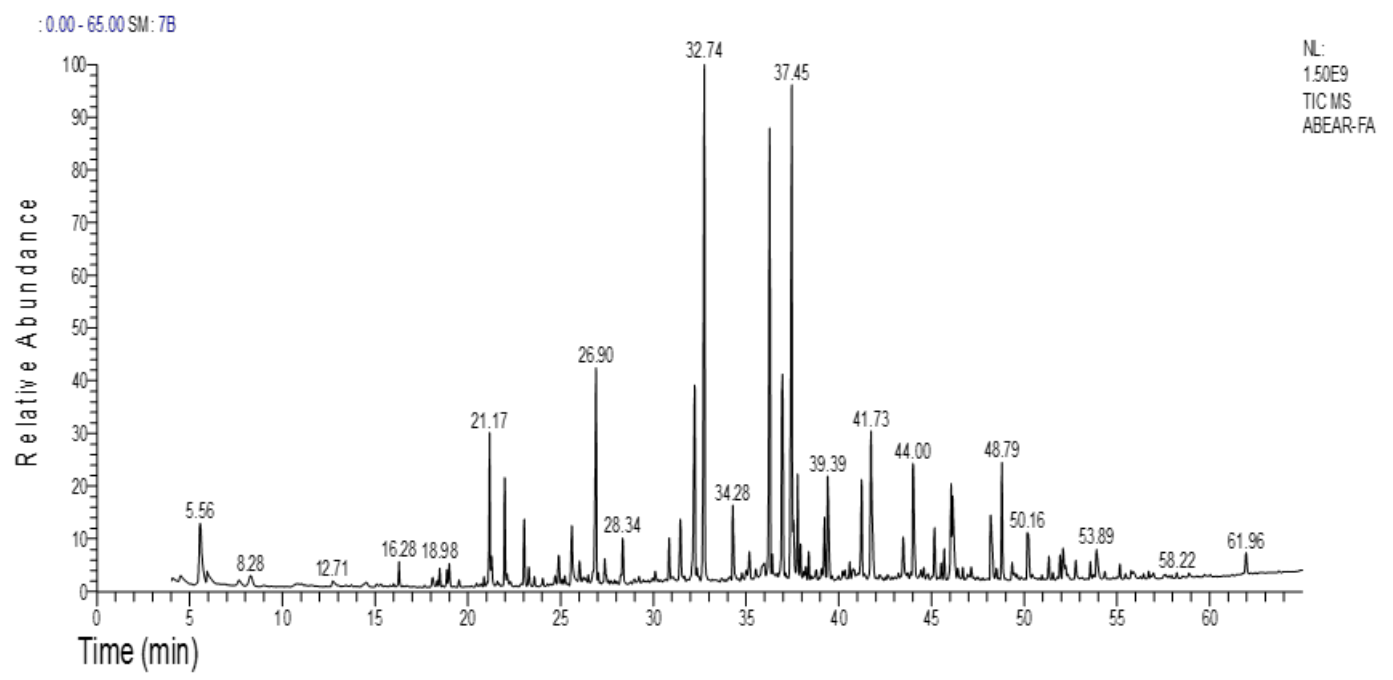

Fig. 2. Gas chromatogram of the fatty acid methyl esters from T. nilotica.

TABLE 2. Fatty acids profile of $\boldsymbol{T}$. nilotica and $P$. dioscoridis.

\begin{tabular}{lccccc}
\hline Name of fatty acid & $\begin{array}{c}\text { Number of } \\
\text { carbon chain }\end{array}$ & Formula & M wt. & FA \% of T. nilotica & FA \% of $\boldsymbol{P}$ dioscoridis \\
\hline Lauric & $\mathrm{C} 12: 0$ & $\mathrm{C}_{12} \mathrm{H}_{24} \mathrm{O}_{2}$ & 200.32 & 0.67 & 0.71 \\
Myristic & $\mathrm{C} 14: 0$ & $\mathrm{C}_{14} \mathrm{H}_{28} \mathrm{O}_{2}$ & 228.37 & 1.23 & 2.97 \\
Pentadecanoic & $\mathrm{C} 15: 0$ & $\mathrm{C}_{15} \mathrm{H}_{30} \mathrm{O}_{2}$ & 242.4 & 0.46 & 0.84 \\
Palmitic & $\mathrm{C} 16: 0$ & $\mathrm{C}_{16} \mathrm{H}_{32} \mathrm{O}_{2}$ & 256.42 & 20.28 & 38.26 \\
Palmitoleic & $\mathrm{C} 16: 1$ & $\mathrm{C}_{16} \mathrm{H}_{30} \mathrm{O}_{2}$ & 254.41 & 0 & 1.84 \\
Heptadecenoic & $\mathrm{C} 17: 0$ & $\mathrm{C}_{17} \mathrm{H}_{34} \mathrm{O}_{2}$ & 270.45 & 0.62 & 0.67 \\
Stearic & $\mathrm{C} 18: 0$ & $\mathrm{C}_{18} \mathrm{H}_{36} \mathrm{O}_{2}$ & 284.84 & 11.68 & 10.83 \\
Oleic & $\mathrm{C} 18: 1$ & $\mathrm{C}_{18} \mathrm{H}_{34} \mathrm{O}_{2}$ & 282.46 & 1.56 & 0.79 \\
Linoleic & $\mathrm{C} 18: 2$ & $\mathrm{C}_{18} \mathrm{H}_{32} \mathrm{O}_{2}$ & 280.45 & 6.27 & 16.72 \\
Linolenic & $\mathrm{C} 18: 3$ & $\mathrm{C}_{18} \mathrm{H}_{30} \mathrm{O}_{2}$ & 278.43 & 1.64 & 16.07 \\
Arachidic & $\mathrm{C} 20: 0$ & $\mathrm{C}_{20} \mathrm{H}_{40} \mathrm{O}_{2}$ & 312.53 & 0.34 & 1.31 \\
Behenic & $\mathrm{C} 22: 0$ & $\mathrm{C}_{22} \mathrm{H}_{44} \mathrm{O}_{2}$ & 340.58 & 1.45 & 2.15 \\
Lignoceric & $\mathrm{C} 24: 0$ & $\mathrm{C}_{24} \mathrm{H}_{48} \mathrm{O}_{2}$ & 368.63 & 0.94 & 1.08 \\
\hline
\end{tabular}




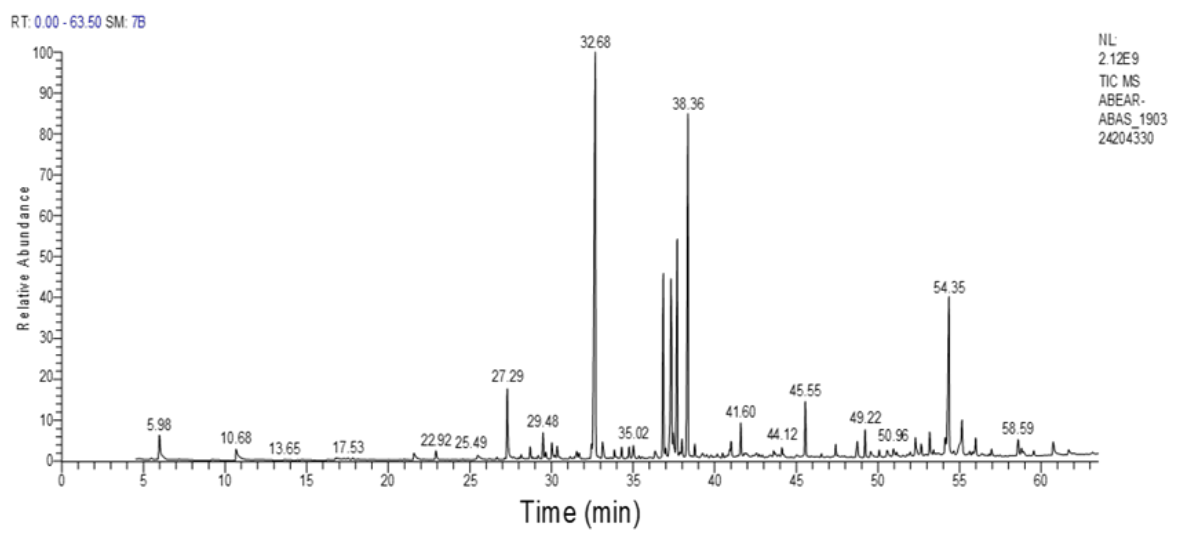

Fig. 3. Gas chromatogram of the fatty acid methyl esters from $P$. dioscoridis.

TABLE 3. Fatty acids composition of $T$. nilotica and $P$. dioscoridis.

\begin{tabular}{lcc}
\hline Lipid composition & T. nilotica & P. dioscoridis \\
\hline Saturated fatty acids (SFAs) & 37.67 & 58.82 \\
Monounsaturated fatty acids (MUFAs) & 1.56 & 2.63 \\
Polyunsaturated fatty acids (PUFAs) & 7.91 & 32.79 \\
Degree of unsaturation (DU) & 17.38 & 68.21 \\
Unsaturation index (UI) & 19.02 & 84.28 \\
\hline
\end{tabular}

TABLE 4. Basic properties of biodiesel from $T$. nilotica and $P$. dioscoridis with biodiesel standards.

\begin{tabular}{|c|c|c|c|c|c|}
\hline \multirow[b]{2}{*}{ Properties } & \multirow[b]{2}{*}{ T. nilotica } & \multirow[b]{2}{*}{ P. dioscoridis } & \multicolumn{3}{|c|}{ Standards } \\
\hline & & & $\begin{array}{c}\text { USA ASTM } \\
\text { D6751 }\end{array}$ & $\begin{array}{l}\text { Europe EN } \\
\text { 14214:2008 }\end{array}$ & $\begin{array}{c}\text { EN } 4213 \\
\text { (biodiesel for } \\
\text { heating purpose) }\end{array}$ \\
\hline $\begin{array}{l}\text { Iodine value } \\
\left(\mathrm{g} \mathrm{I}_{2} / 100 \mathrm{~g}\right)\end{array}$ & 17.25 & 76.81 & & $<120$ & \\
\hline $\begin{array}{l}\text { Saponification value } \\
(\mathrm{mg} / \mathrm{g})\end{array}$ & 97.82 & 196.30 & & & \\
\hline Cetane number & 98.21 & 114.18 & $>47$ & $>51$ & \\
\hline $\begin{array}{l}\text { Cold filter plugging point } \\
\left({ }^{\circ} \mathrm{C}\right)\end{array}$ & 12.48 & 27.80 & & & \\
\hline Oxidative stability (h) & 22.73 & 19.58 & $>3$ & $>6$ & \\
\hline $\begin{array}{l}\text { Higher heating value }(\mathrm{MJ} / \\
\mathrm{kg})\end{array}$ & 45.16 & 46.07 & & & $>35.0$ \\
\hline Density $\left(\mathrm{g} / \mathrm{cm}^{3}\right)$ & 0.871 & 0.870 & & $0.860-0.900$ & \\
\hline $\begin{array}{l}\text { Kinematic viscosity at } \\
40^{\circ} \mathrm{C}\left(\mathrm{mm}^{2} / \mathrm{S}\right)\end{array}$ & 3.88 & 3.88 & $1.9-6.0$ & $3.5-5.0$ & \\
\hline
\end{tabular}

The cetane number $(\mathrm{CN})$ is the most important parameters of biodiesel that indicates the fuel characteristics in terms of ignition and combustion, and its higher value accounts for better ignition (Lanjekar \& Deshmukh, 2016; Suh \& Lee, 2016; Chen \& Chen, 2016). CN in the biodiesel standards of USA (ASTM D 6751) and Germany (DIN 51606) set 47 and 49, respectively (Hoekman et al., 2012), while in European Union set this value at 51(Azam et al., 2005). However, other finding reported that premium diesel fuel must have a $\mathrm{CN}>60$ (Wieselburg, 2004). The CN 
determined for $P$. dioscoridis (114.2) is higher than that of $T$. nilotica (98.2) and both values were within the acceptable limit of the biodiesel standards (Table 4). Previous reports indicated that the higher $\mathrm{CN}$ is related to the higher percentage of SFAs and the higher SN (Akbar et al., 2009). However, the higher the $\mathrm{CN}$, the greater the decrease of IV, and low-IV FAMEs cause solidification even at high temperatures. Therefore, to be considered as promising biodiesel producers, the species must have a suitable CN (Azam et al., 2005) concomitant with high IV. This leads us to think that the most suitable biodiesel is that from $P$. dioscoridis which have suitable engine parameters (SN 196.3, IV 76.81 and CN 114.18).

Cold filter-plugging point (CFPP) evaluate the lowest temperature that make a fuel flow through a standardized filtration device in a specific time (Yuan et al., 2017; Sierra-cantor \& Guerrerofajardo, 2017). In this study, CFPP value for $P$. dioscoridis $\left(27.8^{\circ} \mathrm{C}\right)$ has been found to be higher than that for $T$. nilotica $\left(12.48^{\circ} \mathrm{C}\right)$ (Table 4). Such results attributed to the high saturation of P. dioscoridis oil (Park et al., 2008). However, the CFPP values of both investigated biodiesel considered higher than the recommended temperature range $\left(+5\right.$ to $\left.-44^{\circ} \mathrm{C}\right)$ set by old European biodiesel specifications for different climatic environments (Wauquier, 1995). In general, it is difficult to establish adequate ranges for CFPP values, since all climatic areas have seasonal temperature variability (Hoekman et al., 2012). On the other hand, the selection of biodiesel is primarily related to its oxidative stability (OS) as an important measure to determineits self-life. It has been reported that the auto-oxidation rate of biodiesel is highly affected by the degree of unsaturation as well as location and number of double bonds (Hoekman et al., 2012; Lanjekar \& Deshmukh, 2016; Jose \& Anand, 2016; Kumar, 2017). The European biodiesel standards specify OS (at $110^{\circ} \mathrm{C}$ ) $>6 \mathrm{hrs}$ (Hoekman et al., 2012). Results indicated higher OS values for both $P$. dioscoridis and T. nilotica reached about $19.58 \mathrm{hrs}$ and $22.73 \mathrm{hrs}$, respectively (Table 4). In addition to the previous criteria, high heating value (HHV) is an important criterion for selecting suitable fuels. It isthe heating energy released during the combustion of the unitvalue of fuels (Fassinou et al., 2010). Proper value for this parameter is not quantified in the biodiesel standards ASTM D6751 and EN 14214 but is set in EN 14213 (biodiesel for heating purpose) with a minimum of $35 \mathrm{MJ} / \mathrm{kg}$
(Wieselburg, 2004). In this study, results showed that values of both tested plants exceed the limit set for this criterion (46.07 and $45.16 \mathrm{MJ} / \mathrm{kg}$ for $P$. dioscoridis and T. nilotica, respectively) (Table 4). Such results agree with those previously obtained from Jathropa spp. (Rashid et al., 2009) and some tropical plants (Guil-Layneza et al., 2019).

Density $(\rho)$ is a key fuel property, which directly affects the engine performance characteristics such as cetane number and heating value (Hoekman et al., 2012; Jakeria et al., 2014; Suh \& Lee, 2016).It has been well recognized that denser biodiesel has more energy than petroleumdiesel (Atabani et al., 2012). Data presented in Table 4 showed that the density for $P$. dioscoridis oil was $\left(0.870 \mathrm{~g} / \mathrm{cm}^{3}\right)$ and T. nilotica $\left(0.871 \mathrm{~g} / \mathrm{cm}^{3}\right)$ which in agreement with the Europe EN 14214: 2008 for biodiesel (0.860 $\left.0.900 \mathrm{~g} / \mathrm{cm}^{3}\right)$ (Hoekman et al., 2012). Kinematic viscosity $(\eta)$ has a crucial role for the ability of biodiesel to flow and speed in the combustion chamber, it increases with saturation of fatty acid as well as at low temperature (Atabani et al., 2012; Toscano et al., 2012; Jakeria et al., 2014; Wakil et al., 2015). Previous reports from Agarwal (2007) and Ahmad et al. (2011) indicated that biodiesel is usually $10-15 \%$ higher than the conventional diesel fuels due its large molecular weight and structure. $\eta$ specified by USA ASTM D6751 are $1.9-6.0 \mathrm{~mm}^{2} / \mathrm{s}$ and $3.5-5.0 \mathrm{~mm}^{2} / \mathrm{s}$ by Europe EN 14214:2008. Data presented in Table 4 showed that biodiesel $\eta$ for $P$. dioscoridis and T. nilotica have the same value $\left(3.88 \mathrm{~mm}^{2} / \mathrm{s}\right)$ at $40^{\circ} \mathrm{C}$ which was within the permissible limit of the European biodiesel standards values for $\eta$ (Table 4).

\section{Conclusion}

In conclusion, it should be focused on addressing the global oil shortage by replacing biofuel production from edible crops with renewable natural source of perennial non-edible wild plants. The present results clearly indicate the high potentiality of $T$. niloticafor bioethanolproduction due to its cellulosic content.Additionally, the dataon biodiesel properties obtained using empirical equations for both $P$. dioscoridis and $T$. niloticabased on their FAMEsprofileexhibit that both investigated species meet the most restrictive biodiesel recommended standards, particularly $P$. dioscoridis. Thus, such plants were considered promising candidates provide raw materials for biofuel production. 
Acknowledgements: The author would like to express her sincere appreciation of the help extended by Dr. Hemmat Khattab for her valuable help in collection and identification of investigated species and Dr. Manal Emam for her helpful suggestions.

\section{$\underline{\text { References }}$}

Abideen, Z., Ansari, R., Gul, B., Khan, M. A. (2012) The place of halophytes in Pakistan's biofuel industry. Biofuels, 3(2), 211-220.

Abideen, Z., Hameeda, A., Koyrob, H., Gula, B., Ansaria, R., Khanc, M.A. (2014) Sustainable biofuel production from non-food sources - An overview. Emir. J. Food Agric. 26(12), 1057-1066.

Abideen, Z., Qasim, M., Rizvi, R.F., Gul, B., Ansaria, R., Khan, M.A. (2015) Oilseed halophytes: A potential source of biodiesel using saline degraded lands. Biofuels, 5(6), 241-248.

Agarwal, A.K. (2007) Biofuels (alcohols and biodiesel) applications as fuels for internal combustion engines. Prog Energy Combust Sci. 33, 233-71.

Ahmad, A.L., Yasin, N.H.M., Derek, C.J.C., Lim, J.K. (2011) Microalgae as a sustainable energy source for biodiesel production: A review. Renew Sustain Energy Rev. 15, 584-93.

Ahmad, M., Zafar, M., Sultana, S., Azam, A., Khan, M.A. (2014) The optimization of biodiesel production from A novel source of wild non-edible oil yielding Plant Silybum marianum. International Journal of Green Energy, 11, 589-594.

Akbar, E., Yaakob, Z., Kamarudin, S.K., Ismail, M., Salimon, J. (2009) Characteristic and composition of Jatropha curcasoil seed from Malaysia and its potential as biodiesel feedstock feedstock. Eur. J. Sci. Res. 29, 396-403.

Alptekin, E. (2017) Emission, injection and combustion characteristics of biodiesel and oxygenated fuel blends in a common rail diesel engine. Energy, 119,44-52.

AOAC. (1984) "Official Methods of Analysis", 14 ${ }^{\text {th }} \mathrm{ed}$. The William Byrd Press, Richmond, VA., USA.

Aransiola, E.F., Ojumu, T.V., Oyekola, O.O., Madzimbamuto, T.F., Ikhu-Omoregbe, D.I.O.
(2014) A review of current technology for biodiesel production: State of the art. Biomass Bioenergy, 61, 276-297.

Atabani, A.E., Silitong,a A.S., Badruddin, .IA., Mahlia, T.M.I., Masjuki, H.H., Mekhilef, S.A. (2012) Comprehensive review on biodiesel as an alternative energy resource and its characteristics. Renew Sustain. Energy Rev. 16, 2070-93.

Atabani, A.E., Silitonga, A.S., Ong, H.C., Mahlia, T.M.I., Masjuki, H.H., Badruddin, I.A. et al. (2013) Non-edible vegetable oils: a critical evaluation of oil extraction, fatty acid compositions, biodiesel production, characteristics, engine performance and emissions production. Renew Sustain Energy Rev. 18, 211-45.

Atadashi, I.M., Aroua, M.K., Aziz, A.A. (2010) High quality biodiesel and its diesel engine application: A review. Renew Sustain Energy Rev. 14, 19992008 .

Azam, M., Waris, A., Nahar, N.M. (2005) Prospects and potential of fatty acid methyl esters of some non-traditional seed oils for use as biodiesel in India. Biomass Bioenergy, 29, 293-302.

Balat, M. (2011) Potential alternatives to edible oils for biodiesel production-a review of current work. Energy Convers. Manage. 52, 1479-1492.

Boulos, L., El-Hadidi, N. (1984) "The Weed Flora of Egypt", The American University Press, Cairo, Egypt.

Cassida, K.A., Muir, J.P. Hussey, M.A., Read, J.C., Venuto, B.C., Ocumpaugh, W.R. (2005) Biofuel component concentrations and yields of switch grass in South central US environments. Crop Sci. 45, 682-692.

Chen, F., Dixon, R.A. (2007) Lignin modification improves fermentable sugar yields for biofuel production. Nat. Biotechnol. 25, 759-761.

Chen, W., Chen, J. (2016) Crystallization behaviors of biodiesel in relation to its rheological properties. Fuel, 171, 178-85.

Demirbas, A. (2008) Relationships derived from physical properties of vegetable oil and biodiesel fuels. Fuel, 87, 1743-1748. 
Dhaliwal, S.S., Oberoi, H.S., Sandhu, S.K., Nanda, D., Kumar, D., Uppal, S.K. (2011) Enhanced ethanol production from sugarcane juice by galactose adaptation of a newly isolated thermotolerant strain of Pichia kudriavzevii. Bioresource Technology, 102(10), 5968-5975.

Ding, S., Liu, Y., Zeng, Y., Himmel, M.E., Baker, J.O., Bayer, E.A. (2012) How does plant cell wall nanoscale architecture correlate with enzymatic digestibility? Science, 338, 1055-1060.

Ensinas, A.V., Modesto, M., Nebra, S.A., Serra, L. (2009) Reduction of irreversibility generation in sugar and ethanol production from sugarcane. Energy, 34(5), 680-688.

Eshel, A., Oren, I., Alekperov, C., Eilam, T., Zilberstein, A. (2011) Biomass production by desert halophytes: Alleviating the pressure on the scarce resources of arable soil and fresh water. The European Journal of Plant Science and Biotechnology, 5(2), 48-53.

Fairbairn, N.J. (1953) A modified anthrone reagent. Chem. Ind. 3186.

Fassinou, W.F., Sako, A., Fofana, A., Koua, K.B., Toure, S. (2010) Fatty acids composition as a means to estimate the high heating value (HHV) of vegetable oils and biodiesel fuels. Energy, 35, 4949-54.

Gopinath, A., Puhan, S., Nagarajan, G. (2009) Theoretical modeling of iodine value and saponification value of biodiesel fuels from their fatty acid composition. Renew Energy, 34, 180611.

Gornaś, P., Rudzińska, M. (2016) Seeds recovered from industry by-products of nine fruit species with a high potential utility as a source of unconventional oil for biodiesel and cosmetic and pharmaceutical sectors. Ind. Crops Prod. 83, 329-338.

Guil-Guerrero, J.L., Guil-Laynez, J.L., Guil-Laynez, A. (2014) Assessment of several weeds for bioenergy production. J. Biobased Mater. Bioenergy. 8, 358362.

Guil-Guerrero, J.L., Guil-Laynez, J.L., Guil-Laynez, A. (2017) Bioprospecting for seed oils from wild plants in the Mediterranean Basin for biodiesel production. J. Clean. Prod. 159, 180-193.
Guil-Layneza, J.L., Guil-Guerrerob, J.L., Guil-Laynez, A. (2019) Bioprospecting for seed oils in tropical areas for biodiesel production. Industrial Crops \& Products, 128, 504-511.

Hadar, Y. (2013) Sources for lignocellulosic raw materials for the production of ethanol. In: "Lignocellulose Conversion", pp. 21-38. Springer Berlin Heidelberg.

Haminiuk, C.W.I., Plata-Oviedo, M.S.V., Guedes, A.R., Stafussa, A.P., Bona, E., Carpes. S.T. (2011) Chemical, antioxidant and antibacterial study of Brazilian fruits. Int. J. Food Sci. Technol. 46, 1529-1537.

Hoekman, S.K., Broch, A., Robbins, C., Ceniceros, E., Natarajan, M. (2012) Review of biodiesel composition, properties, and specifications. Renew. Sustain. Energy Rev. 16, 143-169.

Homme, P.M., Gonalez, B., Billard, J. (1992) Carbohydrate content, fructan and sucrose enzyme activities in roots, stubble and leaves of rye grass (Lolium perenne L.) as affected by source/sink modification after cutting. J. Plant Pysiol. 140, 282- 291.

Jakeria, M.R., Fazal, M.A., Haseeb, A.S.M.A. (2014) Influence of different factors on the stability of biodiesel: A review. Renew Sustain Energy Rev. 30, 154-63.

James, C.J. (1995) "The Analytical Chemistry of Foods", Chapman and Hall Press, New York.

Jin, W., Singh, K., Zondlo, J. (2013) Pyrolysis kinetics of physical components of wood and woodpolymers using isoconversion method. Agriculture, 3, 12-32.

Jose, T.K., Anand, K. (2016) Effects of biodiesel composition on its long-term storage stability. Fuel, 177.

Kadam, K.L., McMillan, J.D. (2003) Availability of corn stover as a sustainable feedstock for bioethanol production. Bioresour Technol. 88, 17-25.

Kalayasiri, P., Jayashke, N., Krisnangkura, K. (1996) Survey of seed oils for use as diesel fuels. J. Am. Oil Chem. Soc. 73, 471-474.

Kibazohi, O., Sangwan, R.S. (2011) Vegetable 
oil production potential from Jatropha curcas, Croton megalocarpus, Aleurites moluccana, Moringa oleifera and Pachira glabra: Assessment of renewable energy resources for bio-energy production in Africa. Biomass Bioenergy, 35, 13521356.

Kim, S., Dale, B.E. (2004) Global potential bioethanol production from wasted crops and crop residues. Biomass-Bioenergy, 26, 361-75.

Knothe, G. (2010) Biodiesel and renewable diesel: A comparison. Prog. Energy Combust. Sci. 36, 364-73.

Knothe, G., Razon, L.F. (2017) Biodiesel fuels. Prog. Energy Combust Sci. 58, 36-59.

Kumar, N. (2017) Oxidative stability of biodiesel: Causes, effects and prevention. Fuel, 190, 328-50.

Kumar, S., Singh, S.P., Mishra, I.M., Adhikari, D.K. (2009) Recent advances in production of bioethanol from lignocellulosic biomass. Chem. Eng. Technol. 32, 517-26.

Lanjekar, R.D., Deshmukh, D.A. (2016) Review of the effect of the composition of biodiesel on NOx emission, oxidative stability and cold flow properties. Renew Sustain Energy Rev. 54, 1401-11.

Leung, D.Y.C., Wu, X., Leung, M.K.H. (2010) A review on biodiesel production using catalyzed transesterification. Appl. Energy, 87, 1083-95.

Migahid, A.M. (1978) "Flora of Saudi Arabia", King Saud University Press: Riyadh, Saudi Arabia.

Mishra, A., Patel, M.K., Jha, B. (2015) Non-targeted metabolomics and scavenging activity of reactive oxygen species reveal the potential of Salicornia brachiataas a functional food. J. Funct. Foods, 13, $21-31$.

Mohamed Shameer, P., Ramesh, K., Sakthivel, R., Purnachandran, R. (2017) Effects of fuel injection parameters on emission characteristics of diesel engines operating on various biodiesel: A review. Renew Sustain Energy Rev. 67, 1267-81.

Murphy, J.D., McCarthy, K. (2005) The optimal production of biogas for use as a transport fuel in Ireland. Renew Energy, 30, 2111-27.

Pandey, S., Patel, M.K., Mishra, A., Jha, B. (2015)
Physio-biochemical composition and untargeted metabolomics of cumin (Cuminum cyminum L.) make it promising functional food and help in mitigating salinity stress. PLoS One, 10(12), e0144469.

Park, J.Y., Kim, D.K., Lee, J.P., Park, C., Kim, Y.J., Lee, J.S. (2008) Blending effects of biodiesels on oxidation stability and low temperature flow properties. Bioresour. Technol. 99, 1196-1203.

Patel, A., Arora, N., Sartaj, K., Pruthi, V., Pruthi, P.A. (2016 b) Sustainable biodiesel production from oleaginous yeasts utilizing hydrolysates of various non-edible lignocellulosic biomasses. Renew Sustain Energy Rev. 62, 836-55.

Patel, A., Arora, N., Mehtani, J., Pruthi, V., Pruthi, P.A. (2017) Assessment of fuel properties on the basis of fatty acid profiles of oleaginous yeast for potential biodiesel production. Renewable and Sustainable Energy Reviews, 77, 604-616.

Patel, M.K., Mishra, A., Jha, B. (2016 a) Non-targeted metabolite profiling and scavenging activity unveil the nutraceutical potential of psyllium (Plantago ovata Forsk). Front. Plant Sci. 7, 431.

Patel, M.K., Pandey, S., Brahmbhatt, H.R., Mishra, A., Jha, B. (2019) Lipid content and fatty acid profile of selected halophytic plants reveal a promising source of renewable energy. Biomass and Bioenergy, 124, 25-32.

Poerschmann, J., Spijkerman, E., Langer, U. (2004) Fatty acid patterns in Chlamydomonas sp. as a marker for nutritional regimes and temperature under extremely acidic conditions. Microb. Ecol. 48, 78-89.

Ramirez-Verduzco, L.F., Rodriguez-Rodriguez, J.E., del Rayo Jaramillo-Jacob, A. (2012) Predicting cetane number, kinematic viscosity, density and higher heating value of biodiesel from its fatty acid methyl ester composition. Fuel, 91, 102-111.

Ramos, M.J., Fernandez, C.M., Casas, A., Rodriguez, L., Perez, A. (2009) Influence of fatty acid composition of raw materials on biodiesel properties. Bioresour. Technol. 100, 261-268.

Rashid, U., Anwar, F., Knothe, G. (2009) Evaluation of biodiesel obtained from cottonseed oil. Fuel Process. Technol. 90, 1157-1163. 
Rasmey, A.M., Hassan, H.H., Abdul-Wahid, O.A., Aboseidah, A.A. (2018) Enhancing bioethanol production from sugarcane molasses by Saccharomyces cerevisiae Y17. Egypt. J. Bot. 58, 547-561.

Sajid, Z., Khan, F., Zhang, Y. (2016) Process simulation and life cycle analysis of biodiesel production. Renew Energy, 85, 945-52.

Santi, G., D’Annibale, A., Eshel, A., Zilberstein, A., Crognale, S., Ruzzi, M., Valentini, R., Moresi, M., Petrucciol, M. (2014) Ethanol production from xerophilic and salt-resistant Tamarix jordanis biomass. Biomass and Bioenergy, 61, 73-81.

Schubert, C. (2006) Can biofuels finally take center stage? Nat. Biotechnol. 24, 777-784.

Sierra-cantor, J.F., Guerrero-fajardo, C.A. (2017) Methods for improving the cold flow properties of biodiesel with high saturated fatty acids content: A review. Renew Sustain Energy Rev. 72, 774-90.

Silva de Sousa, L., Rodarte de Moura, C.V., Eduardo de Oliveira, J., Miranda de Moura, E. (2014) Use of natural antioxidants in soybean biodiesel. Fuel, 134, 420-428.

Singh, S.P., Singh, D. (2010) Biodiesel production through the use of different sources and characterization of oils and their esters as the substitute of diesel: A review. Renew. Sustain. Energy Rev. 14, 200-216.

Sitepu, I.R., Garay, L.A., Sestric, R., Levin, D., Block, D.E., German, J.B. et al. (2014) Oleaginous yeasts for biodiesel: Current and future trends in biology and production. Biotechnol Adv. 32, 1336-60.

Soleimani, M., Tabil, L., Panigrahi, S., Opoku, A. (2008) The effect of fiber pretreatment and compatibilizer on mechanical and physical properties of flax fiberpolypropylene composites. J. Polym. Environ. 16, 74-82.

Suh, H.K., Lee, C.S. (2016) A review on atomization and exhaust emissions of a biodiesel fueled compression ignition engine. Renew Sustain Energy Rev. 58, 1601-20.

Takholm, V. (1974) "Student Flora of Egypt", $2^{\text {nd }}$ ed. Cairo University, Cairo, Egypt.
Toscano, G., Riva, G., Foppa Pedretti, E., Duca, D. (2012) Vegetable oil and fat viscosity forecast models based on iodine number and saponification number. Biomass- Bioenergy, 46, 511-6.

Verma, K.C., Verma, S.K. (2015) Biophysicochemical evaluation of Wild Hilly biotypes of Jatroph a curcas for biodiesel production and micropropagation study of eite plant parts. Appl. Biochem. Biotechnol. 175, 549-559.

Verma, P., Sharma, M.P., Dwivedi, G. (2016) Impact of alcohol on biodiesel production and properties. Renew Sustain Energy Rev. 56, 319-33.

Wakil, M.A., Kalam, M.A., Masjuki, H.H., Atabani, A.E., Rizwanul Fattah, I.M. (2015) Influence of biodiesel blending on physicochemical properties and importance of mathematical model for predicting the properties of biodiesel blend. Energy Convers Manag. 94, 51-67.

Wauquier, J.P. (1995) "Petroleum Refining: Crude Oil, Petroleum Products", Process Flowsheets, $1^{\text {st }}$ ed. Technip, Paris.

Wieselburg, B.L.T. (2004) Review on biodiesel standardization world-wide. IEA Bioenergy Task 39, Subtask Biodiesel.

Yadav, S., Mishra, A., Jha, B. (2018) Elevated $\mathrm{CO}_{2}$ leads to carbon sequestration by modulating $\mathrm{C} 4$ photosynthesis pathway enzyme (PPDK) in Suaeda monoicaand S. fruticosa. J. Photochem. Photobiol. B Biol. 178, 310-315.

Yousuf, A. (2012) Biodiesel from lignocellulosic biomass-prospects and challenges. Waste Manag. 32, 2061-7.

Yu, X., Zhao, P., He, C., Li, J., Tang, X., Zhou, J., Huang, Z. (2012) Isolation of a novel strain of Monoraphidium sp. and characterization of its potential application as biodiesel feedstock. Bioresour. Technol. 121, 256-262.

Yuan, M-H., Chen, Y.H., Chen, J.H., Luo, Y.M. (2017) Dependence of cold filter plugging point on saturated fatty acid profile of biodiesel blends derived from different feedstocks. Fuel, 195, 59-68. 


\section{تقييم خصائص الوقود المنتجة من نباتات الاثل النيلي والبرنوف

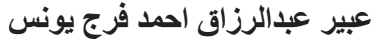 \\ قسم النبات ـ كليه العلوم - جامعه عين شمس ـ القاهرة - مصر.}

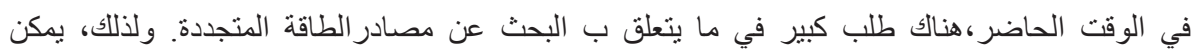

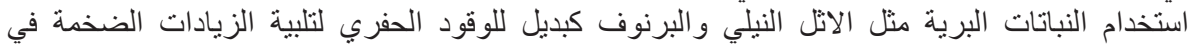

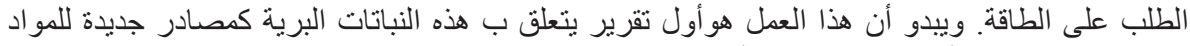

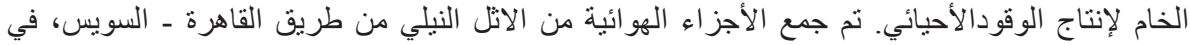

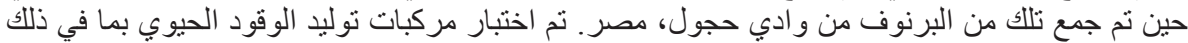

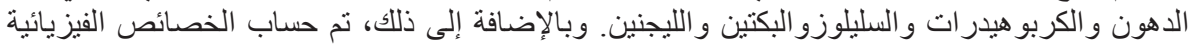

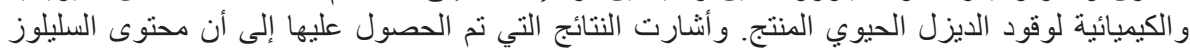

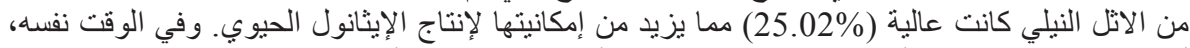

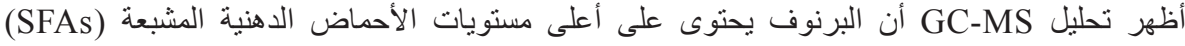

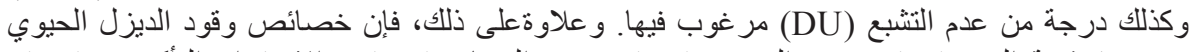

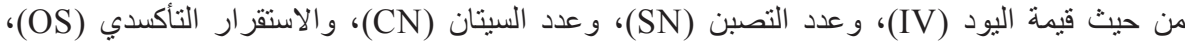

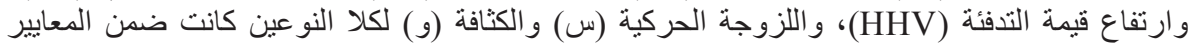

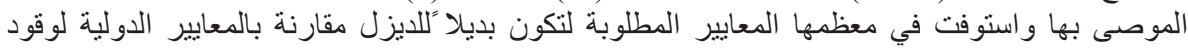

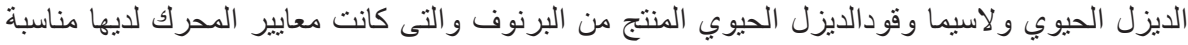

وجيدة 114.18 الن 